\title{
Summary of an international and a regional symposium: Acid-related diseases - improving the treatment options
}

\author{
ABR THOMSON, MD, PHD, FRCPC, FACP
}

ABR THOMSON. Summary of an international and a regional symposium: Acid-related diseases - improving the treatment options. Can J Gastroenterol $1992 ; 6(4): 195-200$. The author examines the clinical impact of findings from a key international workshop on acid peptic disorders, 'Appropriate acid suppression for the healing of acid-related diseases,' and from an important meeting which summarized results of a cross-Canada study of the symptomatic treatment of dyspepsia due to esophagitis and duodenal ulcer disease.

Key Words: Acid-related diseases, Esophageal reflux disease, Summary, Ulcers

Résumé d'un symposium international et régional sur les maladies liées à l'hyperacidité et l'amélioration des thérapeutiques

RÉSUMÉ: L'auteur se penche sur l'impact clinique des découvertes divulguées lors d'un important atelier sur les maladies gastroduodénales intitulé, «Suppression adéquate de l'acidité pour le traitement des maladies liés à l'hyperacidité» [ Appropriate acid suppression for the healing of acid-related disorders"], et lors d'un important congrès qui résumait les résultats d'une étude pancanadienne sur le traitement des symptômes de la dyspepsie attribuable à l'oesophagite et à l'ulcère gastroduodénal.

Division of Gastroenterology, Department of Medicine, University of Alberta, Edmonton, Alberta Correspondence and reprints: Dr ABR Thomson, 519 Robert Newton Research Building, University of Alberta, Edmonton, Alberta T6G 2C2. Telephone (403) 492-6490, Fax (403) 492.7964

Received for publication May 7, 1992. Accepted May 11, 1992
A N INTERNATIONAL WORKSHOP, 'Appropriate acid suppression for, the healing of acid-related diseases', (Hertfordshire, United Kingdom, November 15 to 18,1991 ) and an international symposium, 'Acid-related diseases - improving the treatment options', (Vienna, Austria, November 22, 1991) provided important new information on the treatment of acid peptic disorders. A western Canadian meeting, 'The clinical management of duodenal ulcer and esophageal reflux disease', (Vancouver, British Columbia, January 11, 1992) provided the results of a national study of the symptomatic treatment of dyspepsia due to esophagitis and duodenal ulcer disease using a pump blocker or an $\mathrm{H}_{2}$-receptor blocker. The clinical impact of the new findings reported at these meetings will be examined.

\section{ACID SECRETION}

The sight, smell and thought of food stimulates the hypothalamus which, in turn, stimulates the vagus nerve via 
preganglionic cholinergic $\mathrm{M}_{1}$-receptors; these stimulate the parietal cells in the gastric mucosa. The muscarinic receptors on parietal cells are $\mathrm{M}_{3}$ receptors and these, together with $\mathrm{H}_{2}$ and gastrin-receptors, stimulate gastric acid secretion. Gastric enterochromaffin-like cells also have gastrin-receptors and (at least in the rat) contain granules possessing peptides including histamine. Stimulation of the enterochromaffin-like cells leads to histamine release, which stimulates the $\mathrm{H}_{2}$-receptors on the basolateral membrane of the parietal cell.

Anticholinergic drugs such as pirenzepine act on vagal $M_{1}$-receptors, making their effect on the parietal cell M3-receptors nonspecific and their acid-inhibiting effect modest. The most important receptor on the parietal cell related to acid secretion is the histamine $\mathrm{H}_{2}$-receptor which can be blocked effectively by drugs such as cimetidine, ranitidine, famotidine and nizatidine.

The $\mathrm{H}^{+} / \mathrm{K}^{+}$-ATPase is located on the secretory canalicular membrane of the parietal cell. Irrespective of the stimulus to acid secretion, this proton pump represents the final common pathway in acid secretion and may be blocked by drugs such as omeprazole. Omeprazole, a highly specific inhibitor of the proton pump not affecting $\mathrm{H}^{+} / \mathrm{K}^{+}$-ATPase at other locations, is a prodrug which must be absorbed, metabolized in the parietal cell and bound to the actively secreting canaliculi. Omeprazole is a potent, specific and nonreversible inhibitor of the acid pump, inhibiting acid secretion in both the basal and stimulated state including, importantly, the food-stimulated state.

Therapeutic options for omeprazole include treatment of gastroesophageal reflux disease (GERD) with esophagitis, duodenal and benign gastric ulcer disease, and ulceration associated with hypersecretory states such as the Zollinger-Ellison syndrome. There are possible new roles for omeprazole in the treatment of nonsteroidal anti-inflammatory drugs (NSAID)-associated gastropathy, Helicobacter pylori chronic active gastritis-associated peptic disease and gastrointestinal bleeding.

\section{NSAID-ASSOCIATED MUCOSAL DAMAGE}

Acid present in the gastric lumen may aid the absorption of aminosalicylic acid (ASA) and play a permissive role in the development of nonacidic NSAID damage to the gastric mucosa. Following the acute onset of superficial injury to the gastric mucosa, some healing takes place, leaving deeper focal lesions which may persist for weeks (1). Acid plays at least a permissive role in acute damage, suggested by several observations: the reduction in acid secretion by administration of ranitidine will reduce ASA-associated blood loss (2); cimetidine will diminish ASA-associated mucosal damage (shown by the decreased endoscopic score of mucosal damage) (3); cimetidine 800 $\mathrm{mg}$ at bedtime will reduce duodenal damage induced by oral indomethacin $150 \mathrm{mg} ; 1000 \mathrm{mg}$ ASA-induced endoscopic damage to the gastric mucosa is reduced by omeprazole (4); and omeprazole $40 \mathrm{mg}$ bid reduces gastric blood loss occurring in association with ASA (5).

Most agents used to treat active gastric or duodenal ulcer disease will heal NSAID-associated lesions as long as the NSAIDs are discontinued; however, many patients for whom NSAIDs are prescribed develop disabling joint discomfort when the NSAIDs are stopped. The real issue is to identify an agent which will heal these lesions even when NSAIDs are continued.

Meta-analyses have suggested that approximately $20 \%$ of NSAID-associated gastric ulcers will heal in eight weeks while the patient is treated with placebo compared with $70 \%$ ulcer healing in eight weeks with active agents. In a subset analysis of patients with gastric ulcers treated with ranitidine while NSAIDs were continued, the approximate four- and eight-week healing rates, respectively, were 30 and $53 \%$ for ranitidine, 60 and $80 \%$ for omeprazole $20 \mathrm{mg}$ daily and 80 and $95 \%$ with omeprazole $40 \mathrm{mg}$ daily (6).

There are large, well-conducted control studies suggesting that ranitidine will prevent NSAID-associated duodenal but not gastric ulcers, whereas both types may be prevented with misoprostol (7). It is unknown whether any of these agents are useful in treating congestive gastropathy occurring in portal hypertension. The role of omeprazole in the prevention of NSAID-associated gastric or duodenal ulcers is as yet unknown, but clinical trials are in progress.

\section{HELICOBACTER PYLORI}

\section{AND PEPTIC DISEASES}

Acid normally destroys $H$ pylori, so why does it survive in the gastric lumen? H pylori produces ammonium from endogenous urea by way of $\mathrm{H}$ pylori urease, which likely neutralizes sufficient gastric acid around this bacteria to prevent gastric acid's bactericidal effect. While the food-stimulated gastrin response is higher in $H$ pyloripositive than -negative persons, acid secretion is unaltered. The physiological role of this hypergastrinemia needs to be questioned. Bombesin-stimulated gastrin release is greater in $\mathrm{H}$ pyloripositive than -negative individuals, but again the pathophysiological importance of this hypergastrinemia needs to be established. Both ranitidine and omeprazole reduce $H$ pylori in the short term, but the mechanism of this bacteriostatic effect is unknown. The $H$ pylori often will recur in the gastric antrum, and duodenal ulcer recurrence is common in the presence of $\mathrm{H}$ pylori.

The minimal inhibitory concentrations of antibiotics such as amoxycillin, erythromycin and ciprofloxacin in vitro decrease by an order of magnitude when the intergastric acidity falls and the $\mathrm{pH}$ increases from 3.5 to 5.5 . When omeprazole is given alone, only $4 \%$ of Hpylori-positive patients become negative; however, when omeprazole is combined with amoxycillin for two weeks, $H$ pylori is eradicated in $54 \%$ of patients and six months later, $84 \%$ of these patients have remained free from symptoms of $H$ pylori (8). A German study demonstrated an $\mathrm{H}$ pylori eradication rate of $80 \%$ with no relapses over nine months (9).

While the in vitro activity of metronidazole is not affected by changes in intergastric $\mathrm{pH}$, treating duodenal ulcer patients for 10 days with metronidazole followed by a two-week course of 
amoxycillin plus omeprazole has been reported to result in $60 \%$ eradication (10). The combination of omeprazole, erythromycin and a bismuth compound may also be successful to eradicate $H$ pylori. Thus, omeprazole would appear to improve the effect of some antibiotics to eradicate $H$ pylori, and to heal acute duodenal ulcer and prevent its recurrence. However, the optimal therapeutic approach for treating $H$ pylori has not yet been established.

\section{GASTROINTESTINAL BLEEDING AND STRESS ULCERATION}

Blood clotting and thrombocyte aggregation may be impaired at a low $\mathrm{pH}$; this may provide the rational basis for using an antisecretory agent to stem the flow of bleeding from a peptic ulcer. In an intensive care unit patient bleeding from a peptic lesion, ranitidine $400 \mathrm{mg}$ given over $24 \mathrm{~h}$ by bolus injection was less effective than omeprazole $80 \mathrm{mg}$ given for $24 \mathrm{~h}$ by perfusion (11). It is recommended that intravenous omeprazole be given first as a bolus of 80 $\mathrm{mg}$, followed by $8 \mathrm{mg} / \mathrm{h}$ for $12 \mathrm{~h}$ with 4 $\mathrm{mg} / \mathrm{h}$ thereafter. Occasionally, reversible water retention will be noted in women receiving high doses of intravenous omeprazole. The mechanism of this fluid retention is unknown.

Ongoing studies will establish whether intravenous omeprazole is associated with an increased risk of nosocomial infections, whether the outcome is superior with coagulation therapy plus acid inhibition and whether the underlying ulcer will heal more rapidly when the patient subsequently is switched to an oral preparation.

\section{GASTROESOPHAGEAL REFLUX DISEASE}

How common is GERD? Approximately $40 \%$ of the American population will experience heartburn at least once each month and approximately $10 \%$ will experience heartburn daily. If one bases the diagnosis of GERD on the presence of an abnormal upper gastrointestinal $x$-ray, the prevalence is roughly 86 cases per 10,000 per year, whereas the incidence falls to 4.5 if endoscopy is used as the end-point
(12). Thus, it generally is agreed that the prevalence of GERD depends upon its definition. From the patient's perspective, GERD needs to be treated to reduce the frequency and severity of symptoms; from the physician's perspective it also is important to treat complicated GERD to reduce the complications. Complications: It has been suggested that approximately $20 \%$ of patients with esophagitis will have complications including ulceration $(5 \%)$, stricture $(5 \%)$, hemorrhage $(2 \%$, although possibly occult bleeding is more common) and perforation (less than $0.2 \%$ ). Barrett's epithelium occurs in as many as $10 \%$ of patients with GERD, but it is difficult to be certain of the exact prevalence because insensitivity of the esophagus has been reported in patients with GERD, reducing their pain perception which may hinder detection until development of a stricture, an adenocarcinoma or a post mortem examination. Unfortunately, there are no data to suggest that Barrett's epithelium can be prevented on a regular and predictable basis by either medical or surgical therapy.

Fortunately, the mortality rate from GERD is low (approximately one death per $10^{5}$ per year). Even when GERD is treated appropriately, there is a high rate of recurrence, but this can be prevented with maintenance therapy with an acid-inhibiting drug. Thus, the aim of therapy is to reduce symptoms to a level that does not impair the patient's quality of life and that prevents complications. The recurrence of GERD symptoms and esophagitis is higher in patients treated with standard doses of $\mathrm{H}_{2}$-receptor antagonists than in those treated with omeprazole.

While it generally is accepted that NSAIDs may be associated with gastric (and less commonly duodenal or small intestinal) lesions, it has only recently been recognized that a higher proportion of patients with peptic stricture of the esophagus have used NSAIDs than did a control population with a relative risk of approximately 3:1 (13,14). Patients with GERD without peptic stricture may also have recently used ASA with a relative risk of approximately 2.5:1 (15).
Daytime reflux is important for most patients with GERD, but nighttime exposure also is important for those with severe disease. $\mathrm{H}_{2}$-blockers have a modest effect on food-stimulated acid secretion and a more marked effect on nighttime acid secretion. Several studies have reported the superiority of omeprazole - compared with standard doses of $\mathrm{H}_{2}$-receptor antagonists - for the symptomatic improvement and healing of GERD (16).

It is important when considering these reports, however, that the endpoint is understood; of patients presenting with heartburn and regurgitation, only $61 \%$ will have an abnormal endoscopy, $73 \%$ will have reduced lower esophageal sphincter pressure, $88 \% \mathrm{ab}$ normal Bernstein test and $94 \%$ of patients will have abnormal histology (17). Thus, therapy for GERD may be useful for symptoms, but objective endpoints, such as endoscopic healing, need to be considered. The criteria for endoscopic healing also need to be better standardized. Finally, since it is apparent that patients with GERD generally require greater acid inhibition to achieve healing than do patients with duodenal ulcer, results of high dose $\mathrm{H}_{2}$-receptor antagonist therapy will be awaited with interest.

Over a 12 -month interval, $75 \%$ of GERD patients treated with ranitidine $150 \mathrm{mg}$ bid will recur compared with $68 \%$ treated with omeprazole $20 \mathrm{mg}$ on weekends (Friday, Saturday and Sunday) and only $11 \%$ treated with omeprazole 20 mg daily. In 98 patients with esophagitis resistant to three months of treatment with ranitidine, many were kept in remission with omeprazole $20 \mathrm{mg}$ daily over one year (18). Omeprazole $10 \mathrm{mg} /$ day is more effective in this regard than $20 \mathrm{mg}$ on weekends when given to patients who initially healed their esophagitis on omeprazole (79 versus 46\%) (19).

In patients with grade II or III esophagitis, healing occurred in $60 \%$ of patients at four weeks, $80 \%$ at eight weeks and $100 \%$ at six weeks when treated with omeprazole $40 \mathrm{mg} /$ day (20). In a five-year follow-up of 91 patients, $75 \%$ remained in remission on maintenance therapy with 20 mg daily, but some patients required 40,60 or 80 

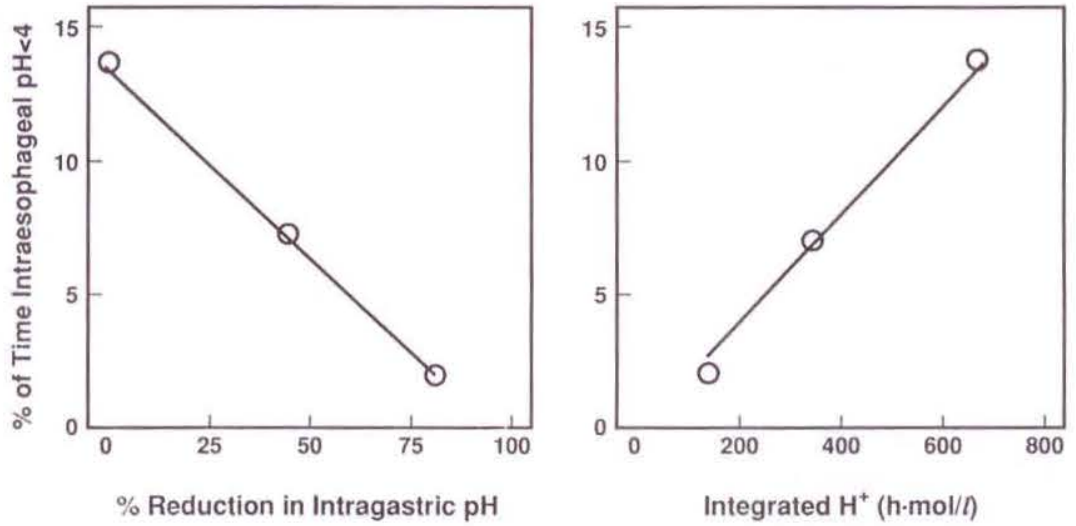

Figure 1) Effect of changes in gastric acidity on esophageal acid exposure (Adapted with permission from Burget et al. Gastroenterology 1990;99:345)

mg/day for maintenance therapy. Few patients with GERD will have acid hypersecretion (21), but duration of acid exposure to the esophagus will also relate to the degree of impairment of the lower esophageal sphincter pressure (or possibly variabilities in the absorption, metabolism and excretion of omeprazole). For example, 15 of 19 GERD patients who relapsed had a lower esophageal sphincter pressure less than $6 \mathrm{mmHg}$ and 18 of 19 had a pressure less than $10 \mathrm{mmHg}$.

What is the rational basis for the use of antisecretory agents to reduce intragastric acidity and thereby achieve healing of GERD? There is an inverse linear relationship between number of hours per day that the intragastric $\mathrm{pH}$ is less than 4 and number of hours per day that the intraesophageal $\mathrm{pH}$ is less than 4 (Figure 1). There is also a linear relationship between the number of hours per day that the intraesophageal $\mathrm{pH}$ is over 4 and the eight-week healing rate of esophagitis (22). For example, there is almost $100 \%$ healing of esophagitis achieved with omeprazole 60 mg taken each morning, which achieves approximately $22 \mathrm{~h} /$ day of intraesophageal $\mathrm{pH}$ over 4 . Symptom severity also is related to acid exposure; the more severe the patient's symptoms or the endoscopic grade of esophagitis, the longer the esophageal $\mathrm{pH}$ is less than 4 .
The superior healing rate of omeprazole compared with standard doses of an $\mathrm{H}_{2}$-blocker may be due to differences in intragastric, and therefore intraesophageal, pH. For example, the percentage of time that the intraesophageal $\mathrm{pH}$ is less than 4 is $2.5 \%$ with omeprazole $20 \mathrm{mg}$ versus $6.3 \%$ with ranitidine $150 \mathrm{mg}$ tid, with 20 versus 49 reflux episodes with omeprazole compared with ranitidine and only an average of 1.5 (compared with four) of these reflux episodes longer than 5 mins. However, ranitidine $300 \mathrm{mg}$ qid may be comparable with omeprazole 20 $\mathrm{mg} /$ day. Of even greater importance is the establishment of a consensus as to whether patients with GERD should be treated in a graded fashion (initially with lifestyle changes and antacids, then with standard doses of $\mathrm{H}_{2}$-blockers and/or promotility agents, and then using pump blockers only for patients with resistant symptoms), or initially be placed on potent acid inhibition.

\section{PEPTIC ULCER DISEASE}

Most patients with duodenal ulcer disease will have antral gastritis; in approximately $80 \%$, the gastritis is caused by $\mathrm{H}$ pylori, in $5 \%$ it may be autoimmune in origin and in 5\% it is of unknown etiology. Chronic active gastritis may progress to atrophy and will be associated with reduced secretion of gastric acid and pepsin, and loss of the integrity of the mucosa. Acid output will fall with increasing atrophy and with increasing age of the patient. $H$ pylori-associated antral gastritis often is associated with duodenal ulcer; atrophy of the gastric body is not associated with duodenal ulcer but may be associated with gastric ulcer. Severe atrophy of the gastric body is associated with an increased risk of the development of gastric cancer (23).

Chronic atrophic gastritis (type $\mathrm{A} / \mathrm{B}$ ) is associated with gastric enterochromaffin-like cell hyperplasia in patients with peptic ulcer disease, usually of the micronodular or linear type. Atrophic gastritis also is associated with hypergastrinemia which, in turn, may have some role to play in enterochromaffin-like hyperplasia. It should be noted, however, that the hy. pergastrinemia of Zollinger-Ellison syndrome and pernicious anemia causes a different (diffuse) form of enterochromaffin-like hyperplasia. In young and middle-aged men with gastritis, the cumulative risk of developing a peptic ulcer within the following 10-year period is $30 \%$ (compared with an almost negligible risk in those with a normal stomach) (24). Thus, the increase in endocrine cell volume density may be related to the severity of the associated gastritis rather than to the effect of associated drug therapy.

Examination of gastric biopsies performed on patients using omeprazole for compassionate reasons for one to four years revealed that none showed neoplastic or dysplastic changes, $14.1 \%$ showed linear and/or diffuse hyperplasia without micronodular hyperplasia and $28.3 \%$ showed some form of enterochromaffin-like hyperplasia; all types of argyrophil cell hyperplasia, however, were present in pretreatment biopsies. In patients treated with omeprazole there was an increase in micronodular hyperplasia from 2.5 to $10.4 \%$ and the number of patients with chronic active gastritis increased from 1 to $13 \%$, particularly in patients over 49 years old. In patients with a history of gastric ulcer without drug treatment, the presence of chronic atrophic gastritis of the gastric body increased from $7 \%$ at the time of ulcer diagnosis 
to $67 \%$ two years later (25); at that point $23 \%$ of all biopsies showed micronodular hyperplasia (26). It would seem, therefore, that over time chronic atrophic gastritis progresses and that this progression to chronic atrophic gastritis - rather than the use of an antisecretory agent - is responsible for the development in micronodular hy. perplasia observed during long term treatment with omeprazole.

From the patient's perspective, improvement in dyspeptic symptoms is important. Symptom relief is achieved with $\mathrm{H}_{2}$-receptor antagonists as well as with pump blockers. In a large Canadian study performed with the assistance of family physicians, general practitioners and gastroenterologists, patients with endoscopically proven esophagitis of different grades and patients with endoscopically or radiologically demonstrated duodenal ulcer were randomized to receive either ranitidine $150 \mathrm{~g}$ bid or omeprazole $20 \mathrm{~g}$ daily (27). Treatment was double-blind and patient symptoms were reassessed (healing of the underlying GERD/ duodenal ulcer was not re-evaluated). A greater percentage of patients treated with omeprazole experienced symptomatic improvement compared with those treated with ranitidine.

There are criticisms of the study, such as the mixed group of patients, use of radiology instead of endoscopy in some duodenal ulcer patients, lack of follow-up endoscopy to correlate healing with symptom improvement and potential subjectivity of the assessment of dyspepsia improvement. Nonetheless, from the patient perspective of pain improvement and relief, the pump blocker was superior to the receptor blocker.

\section{SAFETY EXPERIENCE WITH PUMP BLOCKERS}

Hypergastrinemia develops in many patients treated with antisecretory therapy. Acidification of the antrum normally 'brakes' the release of gastrin from $\mathrm{G}$ cells, allowing antisecretory drugs to remove partially this normal inhibition. Food stimulates gastrin release and causes hypergastrinemia. $\mathrm{H}_{2}$-receptor antagonists only have a modest effect on food-stimulated acid secretion, whereas omeprazole blocks both stimulated and unstimulated acid secretion. In a study of 1208 patients, $55 \%$ had a two- to fourfold increase in gastrin when treated with omeprazole, but the hypergastrinemia peaked within two to four months and quickly returned to normal when the pump blocker was discontinued. It is important to stress, however, that there is enormous variation in plasma gastrin measurements between individuals when they are given omeprazole.

It is even possible that gastrin, by way of its trophic effect on the gastric mucosa, may be useful for ulcer healing or may stimulate ulcer healing by releasing transforming growth factoralpha and epidermal growth factor. (Of course this is speculative, but is an interesting hypothesis.)

The actual risk of developing gastric cancer following gastric surgery is reduced from the time of surgery until 14 years later; between 15 and 20 years there is no difference in cancer rate and after 20 years the relative risk is only 1.7 (unpublished data). It is incorrect to equate clinically reduced gastric acid, mild hypergastrinemia and development of gastric cancer. It should be noted that gastrin levels are decreased after Billroth resection, and the potential risk of stump carcinoma may be related more to bile reflux than to hypergastrinemia. Hypergastrinemia occurs in some patients following gastric surgery, while vagotomy is associated with the same gastrin profile as in patients treated with omeprazole $20 \mathrm{mg}$ daily.

Gastric irradiation performed to reduce gastric acid secretion is not associated with an increased risk of gastric tumours. In patients with pernicious anemia, approximately one patient in 1000 will develop a tumour but serum gastrin is fourfold higher in pernicious anemia patients than in patients treated with omeprazole.

Hypergastrinemia has been suggested in two studies - but refuted in two others - to be associated with an increased risk of colonic polyps or cancer. Three gastrin measurements would need to be performed over 12 months to detect three patients out of 100 with hypergastrinemia greater than $400 \mathrm{pg} /$ $\mathrm{mL}(28)$, and it clearly is unnecessary to monitor serum gastrin levels in patients on either an $\mathrm{H}_{2}$ - or a pump blocker.

Omeprazole has no effect on vitamin $\mathrm{B}_{12}$ metabolism. It has been questioned whether there is an association between gynecomastia and omeprazole, but patient prolactin levels were not reported and there is no known effect of omeprazole on the prolactin system. Cytochrome P450 activity is affected by cimetidine and, to a lesser extent, by ranitidine and omeprazole. Therapeutic doses of omeprazole do not alter the metabolism of ophylline or caffeine but may have an effect on warfarin or phenytoin. Ranitidine, cimetidine and nizatidine (but not famotidine or omeprazole) increase the systemic availability of alcohol by way of their inhibition of the gastric alcohol dehydrogenase activity. The significance of these modest changes is unknown.

\section{SUMMARY}

Chronic atrophic gastritis (type $\mathrm{A} / \mathrm{B})$ and gastric enterochromaffin-like cell hyperplasia may occur in the absence of hypergastrinemia; the enterochromaffin-like cell hyperplasia associated with hypergastrinemia likely is due to the associated chronic activegastritis. The slight increase in the volume and density of gastric enterochromaffin-like cells which occurs in some patients on long term omeprazole may be linked to the age-related progression of chronic active gastritis, rather than to the associated hypergastrinemia or use of a pump blocker.

Healing of esophagitis can be predicted from the inhibitory effect of an antisecretory or intragastric agent and, therefore, from intraesophageal acidity.

Potent acid inhibition may enhance the effect of antibiotics on $H$ pylori-associated chronic antral gastritis, leading to higher rates of its eradication.

Pump blockers may accelerate the healing of peptic lesions occurring in association with continued use of NSAIDs and may be superior to $\mathrm{H}_{2}$ receptor blockers in the relief of dyspeptic symptoms arising from GERD or duodenal ulcer occurring in patients reporting to community physicians. 


\section{REFERENCES}

1. Brodie DA, Chase BJ. Evaluation of gastric acid as a factor in drug-induced gastric hemorrhage in the rat. Gastroenterology 1969;56:206-13

2. Kitchingman GK, Prichard PJ, Daneshmend TK, Walt RP, Hawkey CJ. Enhanced gastric mucosal bleeding with doses of aspirin used for prophylaxis and its reduction by ranitidine. $\mathrm{Br} \mathrm{J}$ Clin Pharmacol 1989;28:581-5.

3. Kimney MB, Silverstein FE, Saunders DR, Chapman RC. Reduction of endoscopically assessed acute aspirininduced gastric mucosal injury with cimetidine. Dig Dis Sci 1987;32:851-6.

4. Bigard MA, Isal JP. Prevention of aspirin-induced gastric lesions by omeprazole in healthy subjects. Gastroenterology 1989;96:A44.

5. Daneshmend TK, Stein AG, Bhaskar NK, Hawkey CJ. Abolition by omeprazole of aspirin-induced gastric mucosal injury in man. Gut 1990;31:514-7.

6. Walan A, Bader J-P, Classen M, et al. Effect of omeprazole and ranitidine on ulcer healing and relapse rates in patients with benign gastric ulcer. N Engl J Med 1989;320:69-75.

7. Graham DY, Stromatt SC, Jaszewski R, White RH, Triadafilopoulos G. Prevention of duodenal ulcer in arthritics who are chronic NSAID users: A multicentre trial of the role of misoprostol. Gastroenterology 1991;100:A75. (Abst)

8. Unge P, Eriksson K, Bergman B, et al. Abstract book of VI International Workshop on Campylobacter, Helicobacter and related organisms. Sydney, Australia, 1991.

9. Bayerdorffer E. Tagung der Deutschen Gesellschaft fur Verdauungs-und Stoffwechselkrank-heiten in Mannheim (FRG), 1991.

10. Rauws EAJ, Tytgat GNJ. Cure of duodenal ulcer association with eradication of Helicobacter pylori. Lancet 1990;335:1233-5.
11. Lamberts R, Creutzfeldt W, Stockmann F, Jacubaschke U, Maas S, Brunner G. Long-term omeprazole treatment in man: Effects on gastric endocrine cell populations. Digestion 1988;39:126-35.

12. Brunnen PL, Karmody AM, Needham CD. Severe peptic oesophagitis. Gut 1969;10:831-7.

13. Heller SR, Fellows IW, Ogilvie AL, Atkinson M. Non-steroidal antiinflammatory drugs and benign oesophageal stricture. $\mathrm{Br}$ Med J 1982;285:167-8.

14. Wilkins WE, Ridley MG, Pozniak AL. Benign stricture of the oesophagus: Role of non-steroidal anti-inflammatory drugs. Gut 1984;25:478-80.

15. Lanas A, Hirschowitz BI. Significant role of aspirin use in patients with esophagitis. J Clin Gastroenterol 1991;13:622-7.

16. Thomson ABR. Medical treatment of gastroesophageal reflux disease: Options and priorities. Hepatogastroenterology 1991;28:405-22.

17. Behar J, Biancani P, Sheahan DG. Evaluation of esophageal tests in the diagnosis of reflux esophagitis. Gastroenterology 1976;71:9-15.

18. Lundell L, Backman L, Ekstrom P, et al. Prevention of relapse of reflux esophagitis after endoscopic healing: The efficacy and safety of omeprazole compared with ranitidine. Scand J Gastroenterol 1991;26:248-56.

19. Zeitoun P, Barbier P, Cayphas J-P, Isal J-P, Carlsson R. Comparison of two dosage regimens of omeprazole $10 \mathrm{mg}$ once daily and $20 \mathrm{mg}$ weekends - as prophylaxis against recurrence of reflux esophagitis. Hepatogastroenterology 1989;36:279. (Abst)

20. Klinkenberg-Knol EC, Jansen MBJ, Festen JPM, Meuwissen SGM, Lamers CBHW. Double-blind multicentre comparision of omeprazole and ranitidine in the treatment of reflux oesophagitis. Lancet 1987;i:349-51.
21. Hirschowitz BI, Griffith JL, Cummings OW. Development of sustained achlorhydria in a patient with the Zollinger-Ellison syndrome treated with omeprazole. Gastroenterology 1991;101:242-6.

22. Hunt RH, Bell NJV, Burget D, Howden C, Wilkinson J. Appropriate acid suppression for the management of gastro-oesophageal reflux disease. Acid-related diseases improving the treatment options. Austria, 1991. (Abst)

23. Cederberg A, Varis K, Salmi HA, Sipponen P, Harkonen M, Sarna S. Young onset peptic ulcer disease and non-ulcer dyspepsia are separate entities. Scand J Gastroenterol 1991;26(Suppl 186):33-44.

24. Sipponen P, Valle J, Varis K, Kekki M, Ihmaki T, Siurala M. Fasting levels of serum gastrin in different functional and morphologic states of the antro-fundal mucosa. An analysis of 860 subjects. Scand J Gastroenterol 1990;25:513-9.

25. Maaroos HI, Salupere V, Uibo R, Kekki M, Sipponen P. Seven-year follow-up study of chronic gastritis in gastric ulcer patients. Scand J Gastroenterol 1985;20:198-204.

26. Havu N, Maaroos HI, Sipponen P. Argyrophil cell hyperplasia associated with chronic corpus gastritis in gastric ulcer disease. Scand J Gastroenterol 1991;26(Suppl 186):90-4.

27. Pare P, Bailey RJ, Archambault AP, et al. Healing of benign gastric and prepyloric ulcers: A prospective, endoscopy-controlled, randomized, double-blind Canadian multicentre study of omeprazole 20 and 40 mg daily and ranitidine $150 \mathrm{mg}$ twice a day. Can J Gastroenterol 1990;4:7-12.

28. Koop H, Arnold R. Long-term maintenance treatment of reflux esophagitis with omeprazole. Prospective study in patients with $\mathrm{H}_{2}$-blocker-resistant esophagitis. Dig Dis Sci 1991;36:552-7. 


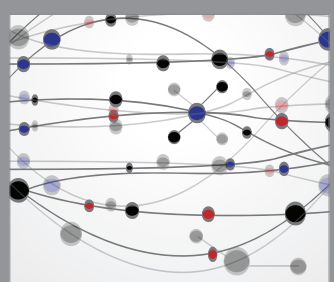

The Scientific World Journal
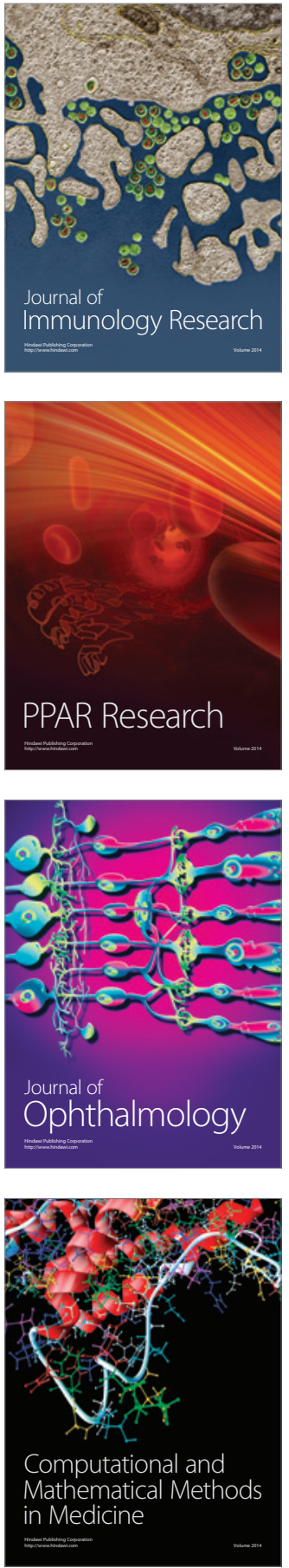

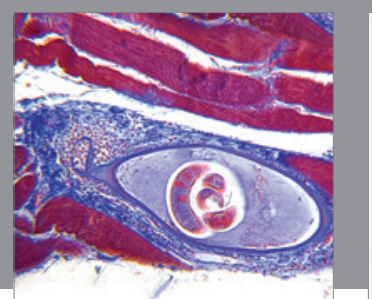

Gastroenterology Research and Practice

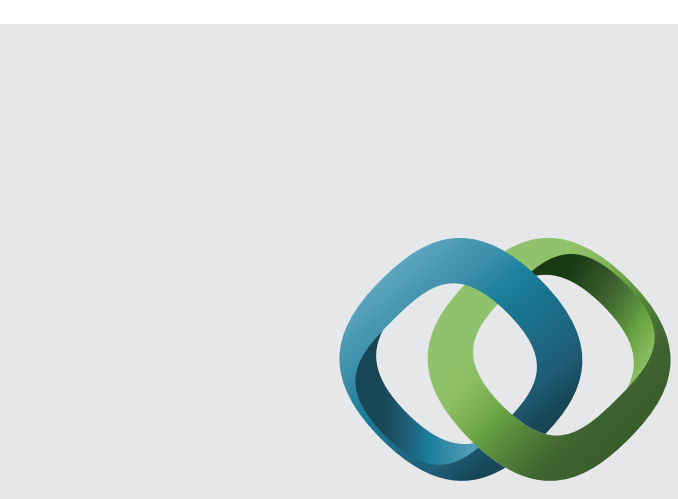

\section{Hindawi}

Submit your manuscripts at

http://www.hindawi.com
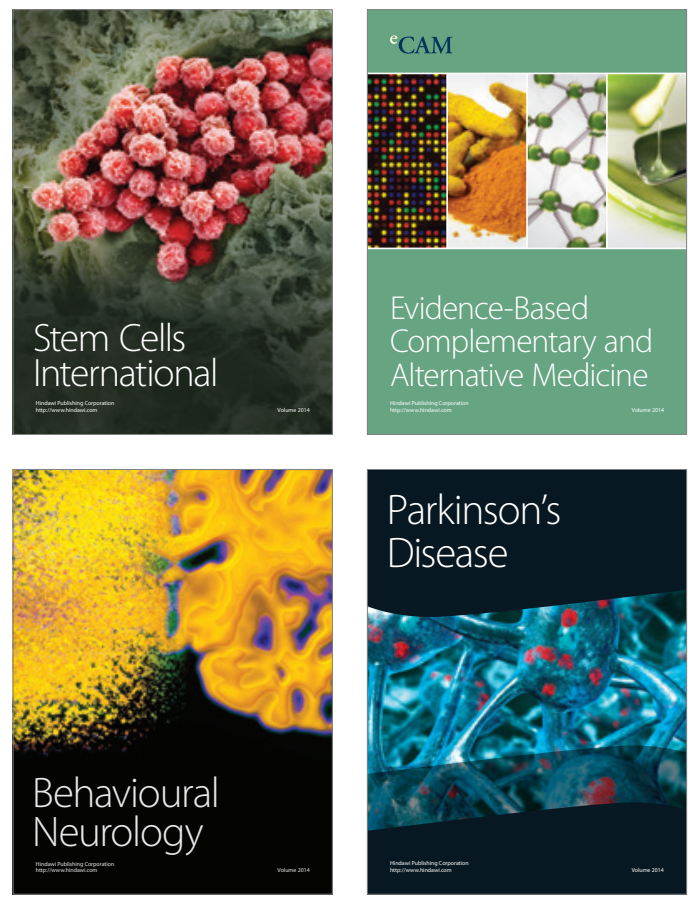
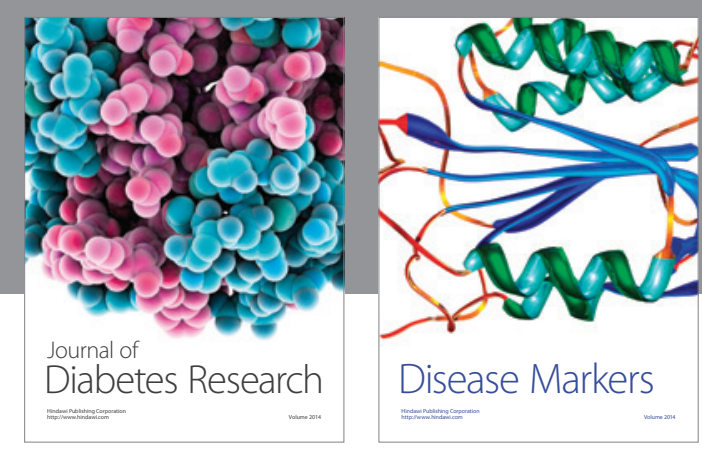

Disease Markers
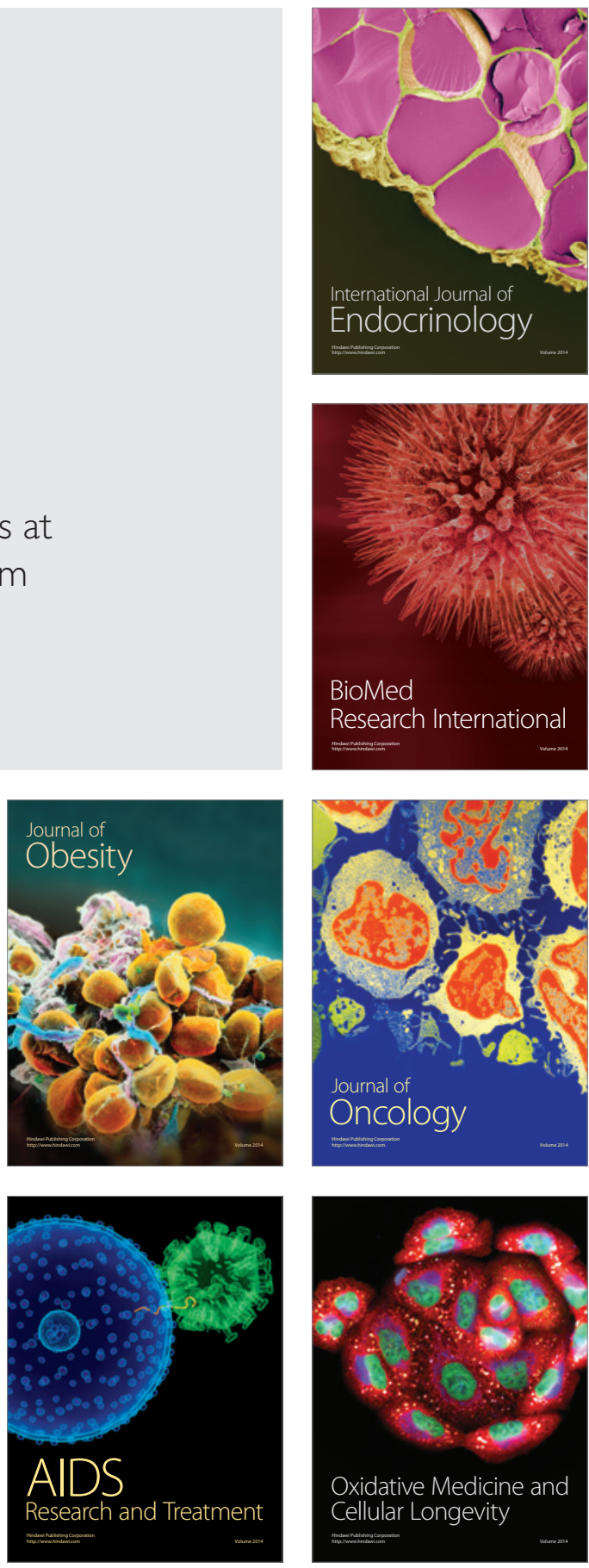